\title{
Diagnostic characters and new populations of Lycopus lucidus var. hirtus (Lamiaceae)
}

\section{Hye-Kyoung Moon, Young-Chul Kim ${ }^{1}$ and Suk-Pyo Hong*}

\author{
Laboratory of Plant Systematics, Department of Biology and Institute of Basic Sciences, Kyung Hee University, Seoul 130-701, Korea \\ ${ }^{1}$ Korea Botanical Garden, Pyeongchang 232-941, Korea
}

(Received 11 May 2013; Revised 29 May 2013; Accepted 8 June 2013)

\section{큰쉽싸리 진단형질 및 신자생지 보고}

\author{
문혜경 · 김영철 ${ }^{1}$ - 홍석표*
}

경희대학교 이과대학 생물학과 및 기초과학연구소, ${ }^{1}$ 한국자생식물원

\begin{abstract}
The natural populations of Lycopus lucidus Turcz. ex Benth. var. hirtus Regel (Lamiaceae) were found in Gangwon province, Korea. This taxon was mainly distinguished from L. lucidus Turcz. ex Benth. var. lucidus by having multicellular hairs on the stem and leaves. However, the delimitation of this taxon from the typical plants of this variety (var. lucidus) was never assessed and the existence of this taxon was obscure in Korea. So, we provide a detailed morphological description of this taxon, as well as its geographical distribution and habitat.
\end{abstract}

Keywords: Lycopus var. hirtus, Lycopus, Lamiaceae

적 요: 큰쉽싸리 (Lycopus lucidus Trucz. ex Benth. var. hirtus Regel) 자연집단의 자생지가 강원도 지역에서 발견되었다. 큰쉽싸리는 잎과 줄기에 많은 털을 갖는 특징으로 쉽싸리(L. lucidus var lucidus)와 구분되는 것 으로 알려져 있으나, 본 본류군의 분류학적 한계는 연구 보고된 바가 없고, 본 분류군의 한반도 분포 역시 명확히 알려진 바가 없다. 따라서, 본 논문에서는 본 분류군의 상세한 형태학적 기재와 지리학적 분포 및 습 성을 제시하였다.

주요어: 큰쉽싸리, 쉽싸리속, 꿀풀과

The genus Lycopus L. is comprised ca. 15 species and distributed mainly in Europe, Asia, and North America (Henderson 1962; Moon and Hong 2006). Lycopus, a perennial herb, occurs mostly in low wetland areas and is distinguished by several gross morphological characteristics such as dentate or pinnatifid leaves, flowers in compact, sessile verticillasters in the leaf axils, and a dry, tetrahedral, one-seeded nutlet with corky crests (Henderson, 1962; Moon and Hong, 2006).

Four species of the genus occur in Korea; Lycopus lucidus ('Swip-ssa-ri'), L. maackianus (Maxim. ex Herder) Makino

\footnotetext{
*Author for correspondence: sphong@khu.ac.kr
}

http://www.pltaxa.or.kr

Copyright $(C) 2013$ the Korean Society of Plant Taxonomists
('Ae-gi-swip-ssa-ri'), L. cavaleriei H. Lév. ('Gae-swip-ssa-ri'), and L. uniflorus Michx. ('Teol-swip-ssa-ri'). L. lucidus is restricted in Northeast Asia and most common species in Korea with a high degree of variability (Moon, 2003). L. lucidus var. hirtus was designated as a variety of L. lucidus var. lucidus by Regel (1862) firstly, since then Kitagawa (1979) was recognized this taxon as L. lucidus Trucz. ex Benth. f. hirtus (Regel) Kitagawa. This taxon was different from the typical plants of this variety (var. lucidus) by having long hairs on its leaves and stem, and has been known in Russia, China, Taiwan and Japan (Regel, 1862; Huang and Cheng, 1978; Kitagawa, 1979; Li and Hedge, 1994). However, the natural population of $L$. lucidus var. hirtus has never been reported in Korea, although Park (1974) and Lee (1996a) briefly mentioned this infraspecific 
taxon. This taxon was first reported by Park (1974) as L. lucidus var. hirtus, and then Lee (1996a) recognized this taxon as a form according to the taxonomic treatment of Kitagawa (1979). They both indicated this taxon was distributed throughout the country, but they didn't provide any voucher information or photos (Park, 1974; Lee, 1996a). In addition, coeval taxonomists didn't recognize the occurrence of this infraspecific taxon of $L$. lucidus var. lucidus in Korea (Chung, 1957; Lee, 1980; Lee, 1996b). Moreover this infraspecies was treated as a synonym of $L$. lucidus var. lucidus since the morphological variation was found within the same populations (Moon, 2003; Hong, 2007). In fact, there are no clear taxonomical studies of this infraspecies even the existence in Korea is still in question.

During general field trips in Korea at 2010-2011, one of authors (Kim, Y.-C.) found several natural populations of $L$. lucidus var. hirtus and noticed several morphological and habitat features which were clearly distinct from $L$. lucidus var. lucidus. So, we report here the occurrence of $L$. lucidus var. hirtus in Korea with detailed morphological description and its known geographical distribution as well as habitat for the first time.

Lycopus lucidus Trucz. ex Benth. var. hirtus Regel, Mém. Acad. Imp. Sci. Saint Pétersbourg, Sér. 7, 4: 115 (1861). - L.

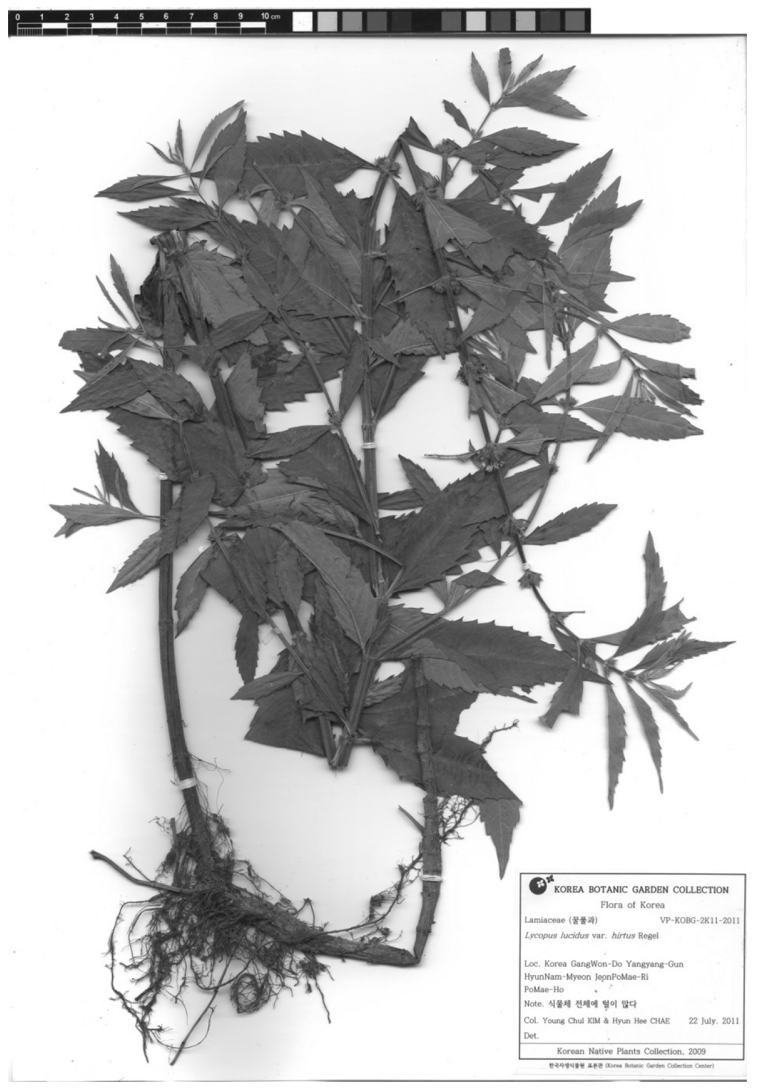

Fig. 1. Voucher specimen of Lycopus lucidus var. hirtus Regel in Korea. lucidus for. hirtus (Regel) Kitag., Neo-Lineam. Fl. manshur. 546 (1979). Type: Russia, Sungacha River (tributary of the Ussuri River), 1895, R. K. Maack (LE, not seen)

Lycopus lucidus Trucz. ex Benth. var. formosanus Hayata, Icon. Pl. Form. 8: 102 (1912); L. formosanus (Hayata) Sasaki, Trans. Nat. Hist. Soc. Taiwan 18: 171 (1928). Type: Sekiko, Taiwan, Nakahaba, G. s.n. (TI, not seen).

\section{Korean Name: Keun-swip-ssa-ri 큰쉽싸리}

Flowering July to August; fruiting August to October.

Herbs perennial, over $1.0 \mathrm{~m}$ tall, rhizomes creeping. Stems square, the angles obtuse, the groove between angles prominent, pubescent, densely pubescent at nodes. Leaves sessile or subsessile, pubescent on both sides; blades $8-15 \mathrm{~cm}$ long, $2.5-4.5 \mathrm{~cm}$ width, elliptic to narrowly ovate, the apex acute to acu-minate, the base cuneate to obtuse, the margin serrate, numerous glandular trichomes on the abaxial side. Inflorescences axillary, in loose verticillate cymes, densely flowered; the bracteoles small, subulate or narrowly triangular, glabrous on both surfaces, the margins serrulate or cilliate. Flowers sess-ile or nearly so; calyx campanulate, glabrous, 5toothed, 3-4 $\mathrm{mm}$ long, the teeth narrowly triangular, equal, spine-tipped, ciliate margin; corolla campanulate, white, 4lobed, the tube shorter than or as long as the calyx; stamens 4 (2 fertile and 2 degenerated); anthers 2-celled, parallel. Nutlets obovate, rounded-truncate at apex, broadly cuneate at base, smooth, ca. $2 \mathrm{~mm}$ long.

Distribution and habitat: Russia, China, Taiwan, Japan and Korea. In Korea, it has found the east side of Gangwon Province mainly at the coastal lagoon areas such as Hwajinpo, Seonyudam, and Pomaeho (Fig. 2).

Examined specimens: Hwajinpo, Hwapo-Ri, Geojin-Eup, Goseong-Gun, Gangwon Province, Korea, 23 Jul. 2010, Kim and Chae s.n. (KHUS); ibid, 9 Aug. 2010, Kim and Chae VPKOBG-2K10-0332, 0333, 0346 (KHUS); ibid, 24 Sep. 2010, Kim and Chae s.n. (KHUS); ibid, 20 May 2011, Kim and Chae s.n. (KHUS); Seonyudam, Gonghyeonjin-ri, Jugwang-myeon, Goseong-Gun, ibid, 21 May 2011, Kim and Chae s.n. (KHUS); ibid, Aug. 2012, Yun s.n. (KHUS); Pomaeho, Jeonpomae-ri, Hyunnam-myeon, Yangyang-Gun, ibid, 22 Jul. 2011, Kim and Chae VP-KOBG-2K11-2011 (KHUS).

We defined the distinct population of L. lucidus var. hirtus, which was clearly distinguished by several diagnostic characters from L. lucidus var. lucidus, so we treated this taxon as a variety of Lycopus lucidus var. lucidus. 


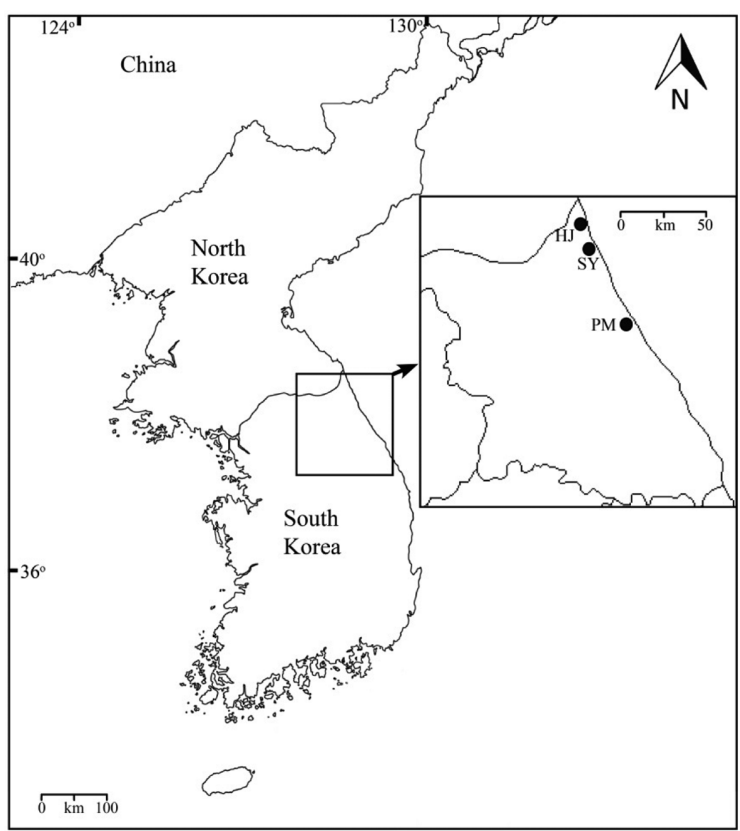

Fig. 2. Known distributional map of Lycopus lucidus var. hirtus in Korea (HJ- Hwajinpo, SY- Seonyudam, PM- Pomaeho, Gangwon Province).

Not surprisingly, Lycopus lucidus var. hirtus is morphologically similar with Lycopus lucidus var. lucidus. Although the hairs on the both sides of leaves and stem of L. lucidus var. hirtus are main diagnostic character to recognize this species, the density of hairs is variable according to the developmental stage of plants. Hair density can be greater in young leaves, and drop off after anthesis. However, the hairs on the midrib of leaves are always dense throughout the plant life cycle. In addition, L. lucidus var. hirtus is much taller (over $1 \mathrm{~m}$ ) and has larger leaves $(8-15 \mathrm{~cm})$ with deeply spinose margin while L. lucidus var. lucidus is $50-100 \mathrm{~cm}$ in height with oblong lanceolate leaves (4-8 cm). Park (1974) and Lee (1996a) indicated L. lucidus var. hirtus as 'Teol-swip-ssa-ri' based on its morphological feature. However, as we already mentioned above, this taxon was treated as a synonym of L. lucidus var. lucidus, the Korean name "Teol-swip-ssa-ri” was given to $L$. uniflorus according to the priority of names and popularities (Chung, 1957; Lee, 1980; Lee, 1996b; Moon, 2003; Hong, 2007). L. uniflorus is characterized by rather short plants 10 $35 \mathrm{~cm}$ with a fusiform tuber, which is obviously different taxon with L. lucidus var. lucidus. Therefore 'Keun-swip-ssa-ri' is nominated as a new Korean name of L. lucidus var. hirtus, although the dense trichomes are the main diagnostic characteristic. It is noteworthy that L. lucidus var. hirtus is restricted in lagoon areas on Gangwon province, while L. lucidus var. lucidus is distributed throughout the country.

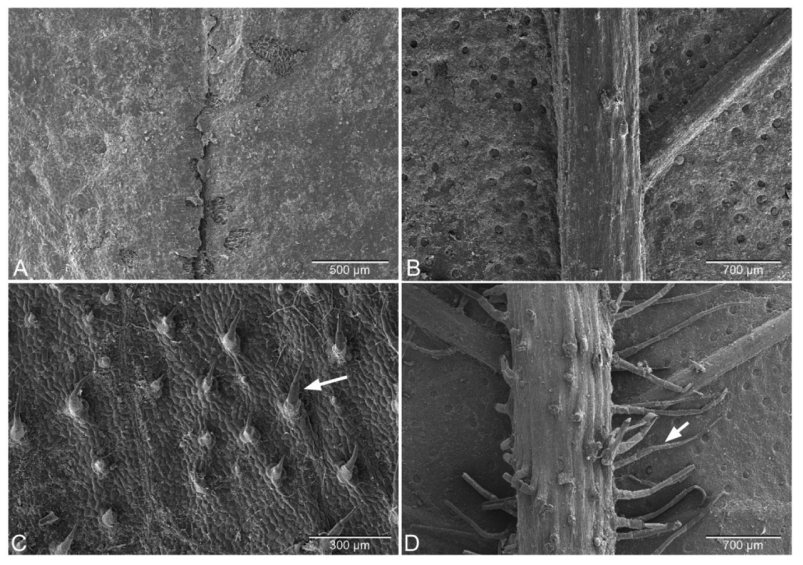

Fig. 3. SEM micrographs of leaf surface to compare existence of trichomes. A-B. Lycopus lucidus var. lucidus, C-D. Lycopus lucidus var. hirtus (A,C; adaxial side, B,D; abaxial side). Arrows indicated the uniseriate multicellular trichomes.

\section{Key of the genus Lycopus in Korea}

1. Rhizomes short, with a fusiform tuber; calyx teeth acute or subacute, not spine tipped; nutlets longer than calyx L. uniflorus 털쉽싸리

1. Rhizomes long creeping, without tuber; calyx teeth aristate-acuminate, spine tipped; nutlets shorter than calyx

2. Leaves oblong-obovate to ovate

L. cavaleriei 개쉽싸리

2. Leaves lanceolate to narrowly lanceolate

3. Stems slender, 20-50 cm tall; leaves narrowly lanceolate, serrate …............................ L. maackianus 애기쉽싸리

3. Stems robust, $>50 \mathrm{~cm}$ tall; leaves oblong-lanceolate, coarsely dentate-serrate

4. Stems glabrous, 50-100 cm tall; leaves glabrous L. lucidus var. lucidus 쉽싸리

4. Stems pubescent, $>100 \mathrm{~cm}$ tall; leaves pubescent

L. lucidus var. hirtus 큰쉽싸리

\section{Acknowledgement}

We thank S.-M. Yun for his helpful information and providing the additional samples of taxa. We are also grateful to our colleagues, M.-J. Kong and J.-H. Song for their various help. H.-K. Moon is a postdoc fellow at Kyung-Hee University (NRF-2012R1A6A3A01040422).

\section{Literature cited}

Chung, T. H. 1957. Korean Flora. Vol. 2. Herbaceous plants. Shinjisa, Seoul. (in Korean)

Henderson, N. C. 1962. A taxonomic revision of the genus Lyco- 
pus (Labiatae). American Midland Naturalist 68: 95-138.

Hong, S.-P. 2007. Lycopus. In The genera of vascular plants of Korea. Park, C-W. (ed.), Academy Publishing Co., Seoul. Pp. 835-836.

Huang, T.-C. and W.-T. Cheng. 1978. Labiatae. In Flora of Taiwan, Vol. 4. Li, H. L., T. S. Liu, T. C. Huang, T. Koyama, and C. E. Devol (eds.), Epoch Publishing Co., Taiwan. Pp. 482-483.

Kitagawa, M. 1979. Neolineamenta Florae Manshuricae: or enumeration of the spontaneous vascular plants hitherto known from Manchuria (north-eastern China) together with their synonymy and distribution. Cramer, Lehre, Germany.

Lee, T. B. 1980. Illustrated Flora of Korea. Hyangmunsa, Seoul. (in Korean)

Lee, W. C. 1996a. Lineamenta Florae Koreae. Academy Publishing, Seoul. (in Korean)

Lee, Y. N. 1996b. Flora of Korea. Kyo-Hak Publishing Co., Seoul. (in Korean)

Li, X and I. C. Hedge. 1994. Lycopus. In Flora of China, Vol. 17. Wu, Z. Y. and P. H. Raven (eds.), Science Press and Missouri Botanical Garden, Beijing and St. Louis. Pp. 239-241.

Moon, H.-K. 2003. Systematics and breeding system of the genus Lycopus L. (Mentheae-Lamiaceae). Ms thesis. Kyung Hee University, Seoul.

Moon, H.-K. and S.-P. Hong. 2006. Nutlet morphology and anatomy of the genus Lycopus L. (Lamiaceae: Mentheae). Journal of Plant Research 119: 633-644.

Park, M.-K. 1974. Keys to the Herbaceous Plants in Korea (Dicotyledoneae). Jeongeumsa, Seoul. (in Korean)

Regel, E. 1862. Tentamen florae Ussuriensis oder versuch einer flora des Ussuri-Gebietes. Mémpores de L'académie Impériale des Sciences de St. Pétersbourg, VIIE SÉRIE. Tome IV, No 4. 